\title{
Explore and Practice of China's Intelligent "New Engineering" — Based on the Grounded Theory
}

\author{
Qin Jingyi, Li Hua, Chen Xiu, and Feng Wen
}

\begin{abstract}
In the era of the Industrial Revolution 4.0, emerging intelligent information technologies represented by the Internet of Things, big data, artificial intelligence, etc. are triggering a new round of educational reforms, driving human education to transition to intelligent education. This article adopts the 612 national-level new engineering research and practice projects released by China in 2018 that involve the integration of new engineering and wisdom education in universities and colleges that also implement the integration of the two in addition to the New Engineering Research and Practice Project, A total of 80 colleges and universities practice samples as research objects, With the help of the grounded theory system, a fusion model consisting of $\mathbf{7 5 5}$ original sentences, 77 concepts, 25 categories, 7 main categories, and 3 core categories-the TCG model. Its integration path is: Block chain: more open and more credible new ideas; Internet + education: the construction of a curriculum system that combines theory and practice with individuality and multiple coexistence; emotional skills perception + cloud computing: intelligent new teachers Strength training; AI + VR: construction of an open and immersive second learning world; big data + the Internet of Things: the establishment of a precise and intelligent management system; big data + artificial intelligence: the construction of a new mechanism of evaluation and incentives; the Internet of Things + none Seamless Interconnection: Comprehensive Perception of Government-Industry-Research Cooperation System.
\end{abstract}

Index Terms - Intelligent education, the new engineering, path analysis, grounded theory.

\section{INTRODUCTION}

Our world today is undergoing a century of great changes. Global technological innovation is restructuring the global innovation landscape and reshaping the global economic structure. At present, human beings are at the forefront of the fourth industrial revolution. Intelligent information technologies represented by artificial intelligence, pervasive computing, virtual reality, big data, block chain, etc. are triggering a new round of educational reform. China's higher education is undergoing a transformation and evolution to smart education. China launched the "New Engineering" plan and created the "Double Era" era, which is regarded as one of the important power engines under the new normal of China's economic development [1].

It is undeniable that the comprehensive use of intelligent technologies such as big data, block chain, artificial intelligence and so on to fully integrate into the whole process of education, and to explore new and innovative

Manuscript received March 18, 2020; revised May 12, 2020.

The authors are with Chongqing University, China (e-mail: 695837885@qq.com). education models in the future have become the key wings of the times. The key to the first battle and the only way for the "intelligent operation" of the new engineering discipline to truly realize the intensive quality development of higher education. Wisdom Education for New Engineering, wisdom education not only brings shock and restructuring, but also brings advantages of platforms and intelligent technology. At the time when the current philosophy, methods, models and mechanisms of new engineering training are facing deep reforms, the wisdom education perspective may provide an effective breakthrough for new engineering courses. The integration of new engineering and smart education is necessary and feasible. The organic integration of the two will further clarify the "new" concept, update the educational concept and training mode of engineering talent training, innovate teaching methods and methods, and form a scientific and complete training system. Finally, it cultivates high-quality innovative engineering and technological talents. However, the current research on the practical effects of the integration of new engineering and wisdom education, as well as the research on the proposed fusion path, need to be improved. On the one hand, research on the fusion of the two is rare. On the other hand, although many universities and research experts have realized the necessity and urgency of the integration of the two, they have started relevant practices and researches on the integration of the two, but most of them focus on a single college, a single type of college or a regional college Exploration and research in the field. Their research has its own models, characteristics, and contents, but the essence of the research is similar. At present, there is a lack of research on systematically summarizing and analyzing the experience and lessons in the implementation process of 612 new engineering research and practice projects that integrate the two, especially for the integration of new engineering and wisdom education in national universities There is almost no research on the implementation of the system and the overall analysis of the system. Based on this, through the analysis of 612 national-level new engineering research and practice projects, involving universities that integrate new engineering and intelligent education, and at the same time conducting comprehensive collection and analysis of documents through How Net, major libraries and other related websites, a total of 72 The university is a sample, and innovatively uses the grounded theory to systematically build a TCG that integrates new engineering and intelligent education, including 669 original sentences, 65 concepts, 25 categories and 7 main categories, and 3 core categories. The model explores the path of the integration of new engineering and wisdom education in colleges and universities, with a view to introducing new ideas. 


\section{ANALYSIS OF RELATED CONCEPTS}

\section{A. New Engineering Course}

In 2016, China introduced the concept of "New Engineering", and officially started the construction of "New Engineering" in 2017, and successively formed "Fudan Consensus", "Tianda Action", and "Beijing Guide". Professor Zhang Denghua defines the connotation of new engineering as: taking morality as the lead, coping with change and shaping the future as the construction concept, and taking the inheritance and innovation as the main route, integration and coordination and sharing as the main ways to cultivate future diversified and innovative engineering talents [2]. He also summarized the characteristics of "new engineering" with "strategic", "innovative", "systematic" and "open". Professor Li Hua and others pointed out that "new engineering" refers to a new engineering form, which is a new engineering form created by injecting new meaning into engineering to meet the needs of economic and social development in the new period. It can be expressed as "engineering +", that is, engineering + New forms of engineering science formed by new concepts, engineering + new specialty, engineering + new structure, engineering + new system, engineering + new technology ... [3].

The so-called new engineering discipline can be understood as a brand-new and innovative discipline that has been fostered by the advent of the new era in order to train outstanding engineering talents in line with the new era. It can also be understood as a new discipline formed by upgrading and upgrading traditional engineering disciplines that are no longer suitable for the development of the new economic era. From this, we can realize the innovation in the meaning of new engineering, which is a foundation for the development of new engineering, and on this basis, the training of outstanding engineering talents is their ultimate destination.

\section{B. Wisdom Education}

When we explain in-depth wisdom education, we need to have a deeper understanding of such a background as education informatization. Educational information technology is a new generation of information technology with artificial intelligence as its core. For example, block chain, Internet of Things, big data, pervasive computing, etc. to build an efficient information technology support environment and integrate it into the entire process of education and training Innovative exploration of new ideas and new methods in the process of education. Based on this, smart education emerged from the cocoon, and has become the advanced stage and future direction of the development of education informatization 2.0.Today's scholars mainly analyze the meaning of wisdom education from two aspects. Some scholars take the philosophical perspective as the starting point and the destination. They believe that the ultimate pursuit of wisdom education is to awaken people's wisdom to seek truth, knowledge, beauty, truth, and behavior. ability. For example, the famous American psychologist Sternberg put forward the wisdom balance theory [4], advocating teaching for wisdom, thinking that education should teach students to think intelligently, solve problems, and cultivate students' social responsibility.
Some researchers have explained the wisdom education from the perspective of information technology. The speech "Smart Earth: Leadership Agenda for the Next Generation" delivered by IBM President and CEO Peng Mingsheng at the Foreign Relations Committee of New York City in 2008 laid the foundation for the emergence of wisdom education [5]. Professor Zhu Zhiting, a scholar in China, points out that wisdom education is to use intelligent technology (smart technology) to build an intelligent environment, so that teachers and students can use smart teaching and learning methods, so as to cultivate good value orientation, high thinking quality and strong behavior. Capable talents [6]. Professor Huang Ronghuai pointed out that wisdom education is a high-end form of education informationization. It is a high-performance talent training system provided by schools, regions or countries. It uses modern information technology to coordinate planning and coordinate the development of education system informationization work. Exploring new methods and ideas of education [7]. Based on this, this article considers that wisdom education is information technology + education, that is, in the information age, it is guided by the development of connotative and quality first-class universities, and uses new information technologies such as the Internet of Things, big data, artificial intelligence, and block chain as The engine collects, analyzes, processes and processes various information about the overall planning and education system, reforms education concepts, uses wisdom teaching methods, builds a wisdom education environment, and cultivates intelligent talents suitable for social development.

\section{Smart New Engineering}

Smart new engineering is a new type of talent training model formed under the integration system of smart education + new engineering. The integration of the two must be feasible because the interaction mechanism between the two can be traced [8]. From the perspective of the supply side, whether it is wisdom education or new engineering subjects, they are facing a new round of scientific and technological revolutions and industrial revolutions, and they are constantly promoting the development of new products, new models, new technologies, and new formats. Facing the common development background of the times. It is necessary to rely on The construction of wisdom education which supporting the development of the scientific and technological revolution and the industrial revolution is fertile soil, Taking the new engineering training model to promote innovation-driven development as the nourishment, Jointly respond to new development opportunities and challenges in the new era of economic and social development. From the perspective of the communication process, in terms of education concepts, both require the development of a comprehensive and innovative education concept in line with the development of the times, and both require the construction of a more open, transparent, decentralized education concept, and the development of the emerging information technology of smart education Can effectively build a new concept from closed to everything connected. In the curriculum system, the new engineering discipline focuses on building a system of integration, innovation, and diversified curriculum support. And smart 
education helps build a multi-level, multi-type and multi-course curriculum system by embedding data sharing, data mining, and intelligent flow. In terms of teaching staff, the new engineering department constructs a teaching staff that combines both theory and practice. The diversity of smart education and information technology exploration can cultivate intelligent and innovative teachers. In the management system, the New Engineering Department explores specialized, modern management mechanisms, organizations, and educational infrastructure and related projects for innovation and entrepreneurship. The use of information technology such as big data and the Internet of Things in smart education can build a precise and intelligent management system to eliminate the existence of administrative and island-type management systems. From the perspective of the feedback section, whether it is wisdom education or new engineering, the main position is to cultivate talents in colleges and universities, and to use human capital as the engine to build the country's freshest human and scientific resources to promote the optimization of industrial structure Economic growth as the ultimate goal of both, The ultimate goal of both is to maximize human welfare and well-being. In summary, the essence of wisdom education and new engineering subjects is to use relevant means to innovate. The ultimate goal and purpose are to return to the human being, and use innovation as the core to cultivate the relevant thinking and ability of students. On the basis of "people" as the support point, according to the law of human development, the overall design, to form a scientific and complete modern system. Based on this, we can understand that intelligent new engineering courses are guided by the use of modern information technology such as artificial intelligence, big data, and the Internet of Things to break boundaries and tap innovation points to deeply integrate into the whole process of new engineering talent training. Cultivate intelligent and innovative talents who are good at autonomous learning, pioneering practice, mastering international cutting-edge innovation technology, have high thinking quality and strong innovation and practical ability to meet the needs of future social development and continuously promote social reform and progress.

\section{ANALYSIS OF THE INTEGRATION OF NEW ENGINEERING AND SMART EDUCATION IN CHINA}

By analyzing the list of the 612 first batch of new engineering practice projects announced by the Ministry of Education of China in March 2018 [8], there are 72 universities and colleges with related literature involving new engineering and smart education integration projects, of which 34 in the east, accounting for $47 \%$ of the total There are 16 in the middle, accounting for $22 \%$ of the total, and 22 in the west, accounting for $30 \%$ of the total. (To save space, see Table I for some items).

TABLE I: UNIVERSITIES INVOLVED NEW ENGINEERING AND SMART EDUCATION INTEGRATION PROJECTS

\begin{tabular}{|c|c|c|c|c|c|c|}
\hline & \multicolumn{2}{|c|}{ Comprehensive college } & \multicolumn{2}{|c|}{ Engineering Advantage Colleges } & \multicolumn{2}{|c|}{ Local high school } \\
\hline & College & project name & College & project name & College & project name \\
\hline East & $\begin{array}{l}\text { Peking } \\
\text { University }\end{array}$ & $\begin{array}{l}\text { Exploration on the } \\
\text { Cultivation of } \\
\text { Innovative and } \\
\text { Entrepreneurial Ability } \\
\text { of "Software }+ \text { " New } \\
\text { Engineering Talents } \\
\end{array}$ & $\begin{array}{l}\text { Tsinghua } \\
\text { University }\end{array}$ & $\begin{array}{l}\text { Intelligent Engineering and } \\
\text { Creative Design }\end{array}$ & $\begin{array}{l}\text { University of } \\
\text { Shanghai for } \\
\text { Science and } \\
\text { Technology }\end{array}$ & $\begin{array}{l}\text { Exploration and } \\
\text { Practice of Cultivating } \\
\text { the "Double } \\
\text { Innovation" Capability } \\
\text { of New Engineering } \\
\text { Talents }\end{array}$ \\
\hline Central & $\begin{array}{l}\text { Hunan } \\
\text { University }\end{array}$ & $\begin{array}{l}\text { Research and Practice } \\
\text { of Multidisciplinary and } \\
\text { Innovative } \\
\text { Entrepreneurship Talent } \\
\text { Training Model Based } \\
\text { on Robot }\end{array}$ & $\begin{array}{l}\text { Hunan } \\
\text { Institute of } \\
\text { Technology }\end{array}$ & $\begin{array}{l}\text { Research and Practice of } \\
\text { Innovative Engineering Applied } \\
\text { Talents Training Mode of } \\
\text { Electronic Information } \\
\text { Specialty Group under the } \\
\text { Background of } \\
\text { Industry-Education Integration }\end{array}$ & $\begin{array}{l}\text { Heilongjiang } \\
\text { August First } \\
\text { Land } \\
\text { Reclamation } \\
\text { University }\end{array}$ & $\begin{array}{l}\text { Exploration and } \\
\text { Research on the } \\
\text { "Internet }+ \text { " Mode of } \\
\text { Cultivating Innovative } \\
\text { Talents in New } \\
\text { Agricultural } \\
\text { Engineering }\end{array}$ \\
\hline west & $\begin{array}{l}\text { Xi'an } \\
\text { Jiaotong } \\
\text { University }\end{array}$ & $\begin{array}{l}\text { Research on the } \\
\text { Cultivation Demands } \\
\text { and Countermeasures of } \\
\text { New Engineering } \\
\text { Talents in Intelligent } \\
\text { Manufacturing }\end{array}$ & $\begin{array}{l}\text { University } \\
\text { of Electronic } \\
\text { Science and } \\
\text { Technology } \\
\text { of China }\end{array}$ & $\begin{array}{l}\text { Constructing a challenging } \\
\text { learning and research-based } \\
\text { teaching system, integrating } \\
\text { engineering practice and } \\
\text { innovative ability into the } \\
\text { whole process }\end{array}$ & $\begin{array}{l}\text { Chengdu } \\
\text { University of } \\
\text { Information } \\
\text { Technology }\end{array}$ & $\begin{array}{l}\text { Research and Practice } \\
\text { on the Integrated } \\
\text { Development Mode of } \\
\text { New Engineering } \\
\text { Practice Teaching } \\
\text { System and Innovation } \\
\text { and Entrepreneurship } \\
\text { Education Based on } \\
\text { CDIO Engineering } \\
\text { Education Concept }\end{array}$ \\
\hline
\end{tabular}

\section{CONSTRUCTION OF A MODEL FOR THE INTEGRATION OF NEW ENGINEERING AND SMART EDUCATION}

\section{A. Research Methods}

Grounded theory was first proposed by sociologists Barney Glaser and Anselm Strauss in their monograph "Discovery of Grounded Theory: Strategies for Qualitative Research" in 1967 [9]. Grounded theory refers to the establishment of a theory based on empirical data. Researchers generally do not have theoretical assumptions before the study begins. They start with actual observations or direct data, summarize the empirical summary from the original data, and then rise to the theory. Grounded theory particularly emphasizes the promotion of theory from data, and believes that only through in-depth analysis of data can a theoretical framework be gradually formed. This is an inductive process, continually condensing data from bottom to top. Different from the general grand theory, the grounded theory does not make logical deduction of the hypothesis set by the researcher himself, but starts with the data to conduct inductive analysis. Based on the open coding, spindle coding, 
and selection coding proposed by the grounded theory, this study analyzes the sample of 612 first new engineering practice projects involving the integration of new engineering and smart education, and deduces the model of the integration of new engineering and innovative entrepreneurship education.

\section{B. Research Object}

This article takes 72 colleges and universities involving the integration of new engineering and smart education among the 612 national new engineering research and practice projects announced by the Ministry of Education and relevant research results. In addition, through the website of HowNet.com, Chongqing University Library, and academic conferences related to higher education, the keywords "new engineering" and "innovation" are all fields, and the results will be searched and searched in 2015-2019 data. The research objects have the following characteristics. First, authoritativeness. The New Engineering Research and Practice Project is a national engineering education reform project awarded by the Ministry of Education. The acceptance and communication mechanism is authoritative. The second is completeness. All 72 sample colleges and universities were screened in accordance with the requirements of the Ministry of
Education. The third is richness. The 72 sample colleges involved pilot schools in different regions of the country's east, middle, and west, including all types of engineering colleges, comprehensive colleges, and local colleges.

\section{Research Process}

Through the refined reading analysis of the collected core data, the qualitative analysis software Nvivo11 was used to screen the original data related to the integration of new engineering subjects and intelligent education in various colleges and universities. The open coding, main axis coding, and selective coding related steps proposed by the grounded theory are used to perform standardized three-level coding to form three focus codes.

1) Concept and category extraction based on open coding

Open coding is to compare and analyze the collected relevant materials, while maintaining an open attitude, reading and analyzing repeatedly word by word and sentence by sentence, and redefining meaningful paragraphs, sentences, and words that are integrated with new engineering and wisdom education. To continuously converge raw materials and categorize them. Based on this, this study obtained a total of 699 original sentences, 65 initial concepts, and 25 categories (see Table II).

TABLE II: SOME CONCEPTS AND CATEGORIES FORMED BY THE INTEGRATION OF OPEN ENGINEERING WITH NEW ENGINEERING AND SMART EDUCATION

\begin{tabular}{|c|c|}
\hline category & concept \\
\hline Innovation of training mode & $\begin{array}{l}\text { New training plan, CDIO talent training model, compound innovative talent training model, flexible } \\
\text { education system }\end{array}$ \\
\hline $\begin{array}{l}\text { Training objectives and professional } \\
\text { settings }\end{array}$ & Interdisciplinary and professional integration, optimization of professional structure, layout of new majors \\
\hline Idea atmosphere & $\begin{array}{l}\text { Decentralization, enhanced openness and transparency, and a more open and credible new engineering } \\
\text { ecosystem }\end{array}$ \\
\hline Relevant policies and legal support & $\begin{array}{l}\text { Improve relevant wisdom education laws and policies, design special funds, complete system, set up special } \\
\text { agency offices, and leadership support }\end{array}$ \\
\hline $\begin{array}{l}\text { Teaching model and method } \\
\text { innovation }\end{array}$ & $\begin{array}{l}\text { Establish a flexible, autonomous, and personalized learning network by category, innovation in teaching } \\
\text { content, digitalization of teaching material content, discussion of teaching methods, and dataization of teaching } \\
\text { management processes }\end{array}$ \\
\hline $\begin{array}{l}\text { Diversified and multi-level mentor } \\
\text { types }\end{array}$ & $\begin{array}{l}\text { The use of information-based communication is convenient to form different tutor structures according to } \\
\text { professional abilities, and multi-type tutor collaboration assistance }\end{array}$ \\
\hline \multicolumn{2}{|l|}{$\begin{array}{l}\text { Exchange and training at home and } \\
\text { abroad }\end{array}$} \\
\hline Flexible curriculum & $\begin{array}{l}\text { Embedded smart functions such as resource sharing, data mining, intelligent flow, and visualization. } \\
\text { Templates are divided into layers and categories, direction design curriculum systems, online and offline } \\
\text { integration, and developmental curriculum systems. }\end{array}$ \\
\hline $\begin{array}{l}\text { Cross-disciplinary cross-curricular } \\
\text { system }\end{array}$ & $\begin{array}{l}\text { "Engineering +" series of courses, multi-academic participation, solid foundation as the prerequisite, } \\
\text { cross-border crossing as the direction, and elimination of academic barriers }\end{array}$ \\
\hline Course content that changes with time & $\begin{array}{l}\text { Internet technology to build a wide range of open and intelligent teaching resources, improve professional } \\
\text { social adaptability, deep integration of curriculum and information technology, an internationally integrated } \\
\text { curriculum system, and continuously improve the level of curriculum }\end{array}$ \\
\hline $\begin{array}{l}\text { Opening and construction of } \\
\text { laboratories }\end{array}$ & Fully open VR virtual teaching laboratory and research laboratory \\
\hline $\begin{array}{l}\text { International Exchange Fund Project } \\
\text { Support }\end{array}$ & $\begin{array}{l}\text { Special international exchange plan, group cooperation among international organizations, and reference from } \\
\text { domestic and foreign experience models }\end{array}$ \\
\hline Immersive platform construction & $\begin{array}{l}\text { Digital teaching practice environment, innovation space construction, school-enterprise joint sharing } \\
\text { platform, competitions and related projects, cross-disciplinary cross-platform }\end{array}$ \\
\hline Financial support and protection & Funding support and resource guarantee \\
\hline $\begin{array}{l}\text { Multi-dimensional integration } \\
\text { resources }\end{array}$ & $\begin{array}{l}\text { Big data and the Internet of things through RFID, benefit sharing responsibility sharing, integration of } \\
\text { government, enterprises, schools and other resources }\end{array}$ \\
\hline School-enterprise collaboration & $\begin{array}{l}\text { Build a seamless, stable, secure, and easy-to-use information circulation and data transmission channel, which } \\
\text { can be collaborative, adaptive, and friendly school-enterprise integration, production-education integration, } \\
\text { multi-dimensional and multi-form cooperation inside and outside the school }\end{array}$ \\
\hline $\begin{array}{l}\text { Rich three-dimensional evaluation } \\
\text { indicators }\end{array}$ & $\begin{array}{l}\text { Multi-dimensional and multi-gradient evaluation systems and assessment methods using information } \\
\text { technology such as emotion perception and cloud computing }\end{array}$ \\
\hline Student-centered & on the effectiveness of student growth, professional education evaluation and professional certific \\
\hline
\end{tabular}


2) Main category extraction based on spindle encoding

The purpose of the main axis coding is to construct the main category of the representative model. Based on the extraction of various categories and concepts in the context of open coding, we explored and considered the interrelationships and internal connections between the various categories. Through the integration, focus and classification of data, we selected the main category that best reflected the research theme (Table III).

TABLE III: MAIN CATEGORY EXTRACTION BASED ON SPINDLE ENCODING

\begin{tabular}{|c|c|c|}
\hline Main category & category & concept \\
\hline \multirow{4}{*}{ Top-level design } & Innovation of training mode & $\begin{array}{l}\text { New training plan, CDIO talent training model, compound innovative talent training } \\
\text { model, flexible education system }\end{array}$ \\
\hline & $\begin{array}{l}\text { Training objectives and } \\
\text { professional settings }\end{array}$ & $\begin{array}{l}\text { Interdisciplinary and professional integration, optimization of professional structure, } \\
\text { layout of new majors }\end{array}$ \\
\hline & Idea atmosphere & $\begin{array}{l}\text { Decentralization, enhanced openness and transparency, and a more open and credible new } \\
\text { engineering ecosystem }\end{array}$ \\
\hline & $\begin{array}{l}\text { Relevant policies and legal } \\
\text { support }\end{array}$ & $\begin{array}{l}\text { Improve relevant wisdom education laws and policies, design special funds, complete } \\
\text { system, set up special agency offices, and leadership support }\end{array}$ \\
\hline \multirow{3}{*}{ Faculty } & $\begin{array}{l}\text { Teaching model and method } \\
\text { innovation }\end{array}$ & $\begin{array}{l}\text { Establish a flexible, autonomous, and personalized learning network by category, } \\
\text { innovation in teaching content, digitalization of teaching material content, discussion of } \\
\text { teaching methods, and dataization of teaching management processes }\end{array}$ \\
\hline & $\begin{array}{l}\text { Diversified and multi-level } \\
\text { mentor types }\end{array}$ & $\begin{array}{l}\text { The use of information-based communication is convenient to form different tutor } \\
\text { structures according to professional abilities, and multi-type tutor collaboration assistance }\end{array}$ \\
\hline & $\begin{array}{l}\text { Exchange and training at } \\
\text { home and abroad }\end{array}$ & \\
\hline \multirow{3}{*}{ curriculum structure } & Flexible curriculum & $\begin{array}{l}\text { Embedded smart functions such as resource sharing, data mining, intelligent flow, and } \\
\text { visualization. Templates are divided into layers and categories, direction design curriculum } \\
\text { systems, online and offline integration, and developmental curriculum systems. }\end{array}$ \\
\hline & $\begin{array}{l}\text { Cross-disciplinary } \\
\text { cross-curricular system }\end{array}$ & $\begin{array}{l}\text { "Engineering +" series of courses, multi-academic participation, solid foundation as the } \\
\text { prerequisite, cross-border crossing as the direction, and elimination of academic barriers }\end{array}$ \\
\hline & $\begin{array}{l}\text { Course content that changes } \\
\text { with time }\end{array}$ & $\begin{array}{l}\text { Internet technology to build a wide range of open and intelligent teaching resources, } \\
\text { improve professional social adaptability, deep integration of curriculum and information } \\
\text { technology, an internationally integrated curriculum system, and continuously improve the } \\
\text { level of curriculum }\end{array}$ \\
\hline \multirow{4}{*}{ Hatching base } & $\begin{array}{l}\text { Opening and construction of } \\
\text { laboratories }\end{array}$ & Fully open VR virtual teaching laboratory and research laboratory \\
\hline & $\begin{array}{l}\text { International Exchange Fund } \\
\text { Project Support }\end{array}$ & $\begin{array}{l}\text { Special international exchange plan, group cooperation among international organizations, } \\
\text { and reference from domestic and foreign experience models }\end{array}$ \\
\hline & $\begin{array}{l}\text { Immersive platform } \\
\text { construction }\end{array}$ & $\begin{array}{l}\text { Digital teaching practice environment, innovation space construction, school-enterprise } \\
\text { joint sharing platform, competitions and related projects, cross-disciplinary cross-platform }\end{array}$ \\
\hline & $\begin{array}{l}\text { Financial support and } \\
\text { protection }\end{array}$ & Funding support and resource guarantee \\
\hline \multirow{2}{*}{$\begin{array}{l}\text { National Institute of } \\
\text { Advanced Industrial } \\
\text { Science and } \\
\text { Technology }\end{array}$} & $\begin{array}{l}\text { Multi-dimensional integration } \\
\text { resources }\end{array}$ & $\begin{array}{l}\text { Big data and the Internet of things through RFID, benefit sharing responsibility sharing, } \\
\text { integration of government, enterprises, schools and other resources }\end{array}$ \\
\hline & $\begin{array}{l}\text { School-enterprise } \\
\text { collaboration }\end{array}$ & $\begin{array}{l}\text { Build a seamless, stable, secure, and easy-to-use information circulation and data } \\
\text { transmission channel, which can be collaborative, adaptive, and friendly school-enterprise } \\
\text { integration, production-education integration, multi-dimensional and multi-form } \\
\text { cooperation inside and outside the school }\end{array}$ \\
\hline \multirow{3}{*}{$\begin{array}{l}\text { Competency-oriente } \\
\text { d evaluation system }\end{array}$} & $\begin{array}{l}\text { Continuous dynamic } \\
\text { evaluation process }\end{array}$ & $\begin{array}{l}\text { The evaluation process is interconnected, and the entire process is monitored and } \\
\text { controlled }\end{array}$ \\
\hline & $\begin{array}{l}\text { Rich three-dimensional } \\
\text { evaluation indicators }\end{array}$ & $\begin{array}{l}\text { Multi-dimensional and multi-gradient evaluation systems and assessment methods using } \\
\text { information technology such as emotion perception and cloud computing }\end{array}$ \\
\hline & Student-centered & $\begin{array}{l}\text { Based on the effectiveness of student growth, professional education evaluation and } \\
\text { professional certification }\end{array}$ \\
\hline
\end{tabular}

\section{3) Core category extraction based on selective coding}

Selective coding is also known as "core landing", and its role is to further dig the intrinsic relationship between the categories in the main axis code, and build a core concept in the main category that can connect the whole together and has a high degree of relevance, Or is called "core generics [10]." This research focuses on the integration of new engineering and wisdom education, and defines it as the core category. The seven main categories derived from the main shaft code are extracted from the core categories, and finally the concept atmosphere, cultivation positioning innovation, cultivation model innovation, professional discipline setting, and related laws and policies are extracted as the top-level design, which plays a directional, guiding, and basic role. The role of the teacher team, the curriculum system, the combination of government-industry-study-research, and the establishment of incubation bases as catalysts, as an important condition for the effective integration of the two, and continuously catalyze and promote the organic integration of the two; student-oriented evaluation

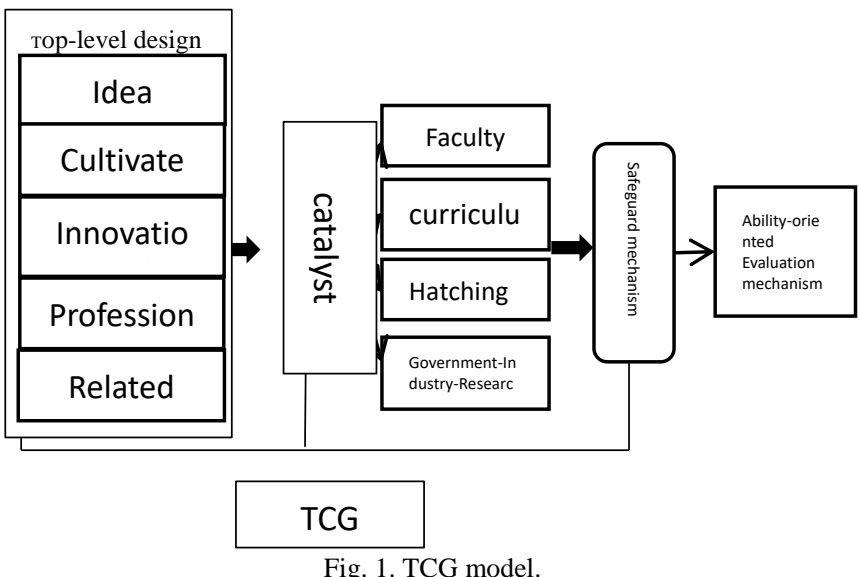

Fig. 1. TCG model. 
The system is extracted as a guarantee mechanism, with students as the center. Through the monitoring and evaluation of their learning, they constantly adjust the various links of the top-level design and catalyst in the integration process to ensure that the integration of the two is always moving in the right direction. This extracts the three core categories of top-level design, catalyst, and guarantee mechanism, namely Top-level design-Catalyst-Guarantee, referred to as TCG model (see Fig. 1).

\section{PATH ANALYSIS OF ORGANIC INTEGRATION OF SMART EDUCATION AND NEW ENGINEERING}

Through the above explanation of the connotation and essence of intelligent new engineering talents, combined with the current status analysis of new engineering subjects, the analysis of the impact and restructuring, opportunities and challenges brought about by intelligent education to the new engineering reform of colleges and universities, and build the intelligent new engineering integration path model. Its integration path is: Blockchain: the creation of a more open and credible new concept; Internet + Education: The construction of a curriculum system that combines theory and practice with personality and multiple coexistence; Emotional skills perception + cloud computing: Intelligent linkage and new teacher training; AI + VR: Open and immersive second learning world construction; Big data + Internet of things: the establishment of a precise and intelligent management system; big data + artificial intelligence: the construction of a new evaluation and incentive mechanism; Internet of things+ seamless interconnection: a comprehensive perception of the government-industry-university-research cooperation system. To this end, a path model for the integration of smart education + new engineering can be constructed as follows (Fig. 2):

\section{A. Block Chain: The Creation of a More Open and Credible New Concept}

Ideology has an important leading and supporting role in action. The theoretical and practical development of China's new engineering disciplines is still in its infancy, and currently lacks a certain degree of systemicity and theory. Undoubtedly, the new engineering disciplines developed under the background of smart education eventually formed a linkage system from closed to interconnected with all things and comprehensive perception. Under the support of a series of information technologies such as the Internet of Things, big data, and cloud computing, everyone, Intelligent analysis and judgment can be performed at any time and every place. Therefore, the concept of the new engineering discipline in the intelligent era should run through the entire process of talent training in a more open state. Using the open and credible characteristics of the block chain to start from the top-level design, the concept of informatization construction is deeply embedded in the hearts of every manager and participant, the importance of information technology for the construction of new engineering disciplines is strengthened, and guidance and publicity are strengthened. At the same time, actively learn from the excellent experience of the integration of the two at home and abroad, explore the path of integration of new engineering and wisdom education, make full use of the advantages of social media and campus media, create a good cultural atmosphere, decentralize, and enhance openness And transparency, to create a more open and credible new engineering ecosystem.

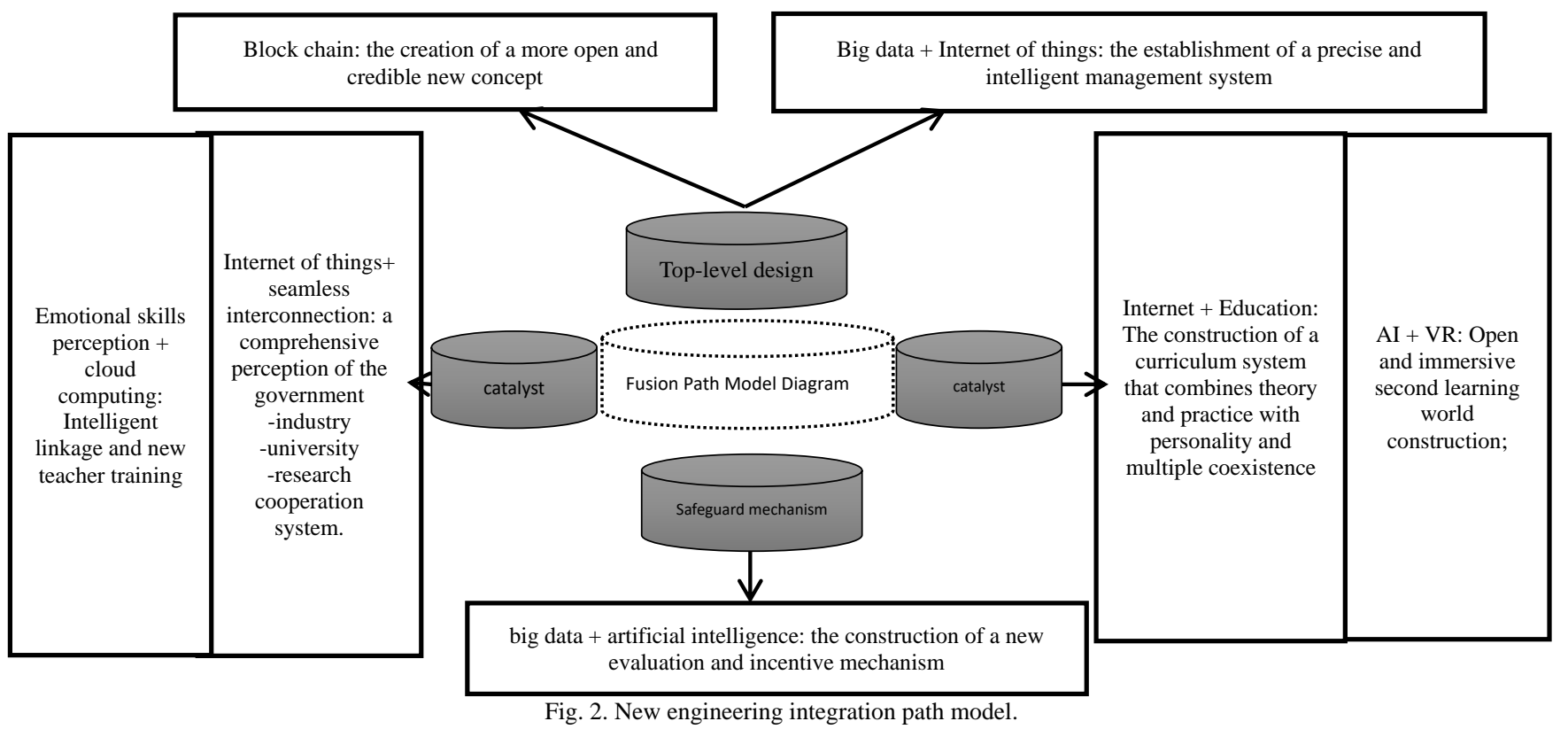

B. Internet + Education: The Construction of a Curriculum System that Combines Theory and Practice with Personality and Multiple Coexistence

Classroom education is an important form of talent training in universities. In order to deepen the implementation of the new engineering concept, in the context of smart education, we should use Internet + education information technology to collect and analyze data and embed smart functions such as resource sharing, data mining, intelligent flow and visualization, according to the different needs and interests of students, it is divided into 
levels, multiple types, and various forms [11]. It insists on problem-oriented, market-oriented, industrial-oriented, and demand-oriented, breaks through the traditional curriculum system, and is brave in innovation, establishing a multi-disciplinary and interdisciplinary curriculum system. Use Internet technology to build a wide range of open and intelligent teaching resources, such as MOOCs and NetEase Cloud Open Classes, to enable seamless integration and barrier-free circulation of high-quality global education resources, and to establish a flexible, autonomous, and personalized learning network by category. On the basis of Internet + , use STEAM, research-based learning, flipped classroom and other technical teaching methods to develop a modular practical curriculum system, guided by teachers' cutting-edge research projects, effective internal and external training platforms and theoretical learning modules Combining, the practice of a theory of knowledge and a practice of practice alternately, effectively integrating classroom teaching and practical training.

\section{Emotional Skills Perception + Cloud Computing: Intelligent Linkage and New Teacher Training}

The mission and purpose of the teacher is to conform to the development of the times, and to train students' knowledge, ideas, and skills in a targeted and planned manner. They are the main guides and communicators for students. In the era of smart education, first of all, teachers should have information-oriented thinking and consciousness. According to the country's strategic needs, the needs of social development, and the needs of students' own interests, innovate teaching resources, reform educational design, and improve the quality of education and teaching. Utilize information technology such as emotion perception and cloud computing to master the development status of students, tap students' potentials [12], support the assessment and dynamic monitoring of the academic level of individual students and groups, and help students with intelligent learning have reached their own intelligent teaching.

At the same time, universities use information technology to explore a variety of teacher supplement channels, establish an open, inclusive, professional and combined teacher team, introduce social forces such as entrepreneurs, investors, or entrepreneurial successers to enter colleges as part-time teachers, and encourage teachers to actively participate in new Engineering construction and practice, strengthen communication and cooperation with enterprises, guide students to participate in innovation and entrepreneurship practices, and strengthen the linkage of teachers.

\section{AI + VR: Open and Immersive Second Learning World Construction}

In order to effectively train intelligent new engineering talents, in addition to attaching importance to the development of classroom teaching, in addition to the classroom, we should also build a smart and orderly bridge between new engineering subjects. Create a smart new engineering incubation base, for example, using the combination of information technology such as AI + VR, to create a smart and immersive second learning environment for new engineering, allowing students to be immersive, face reality, perceive learning scenarios, identify learning To provide suitable learning resources and support tools to achieve personalized education. Compared with traditional incubation bases, the construction of a smart new engineering incubation base has maximized the students 'innovative ability. Through open learning situations, divergent thinking, stimulate students' potential, and guide students to actively build knowledge.

\section{E. Big Data + Internet of Things: the Establishment of a Precise and Intelligent Management System}

Wisdom education will also innovate the management system of new engineering disciplines, construct an information-based smart management system, and to a certain extent improve the traditional management system's unclear powers and responsibilities, unsmooth communication, and island-style shortcomings. The use of big data and the Internet of Things through radio frequency identification (RFID), infrared induction, QR code, global positioning and other information technologies can achieve automatic data collection, centralized storage, intelligent analysis and intelligent push [13], providing managers with more An open, comprehensive and dynamic data system helps managers to make correct decisions, discover problems in the management process in a timely manner, and communicate and cooperate with other management departments.

At the same time, the construction of an intelligent management system can also draw suggestions for managers to actively participate from multiple subjects, such as teachers and students, to eliminate the "administrative," island-like "fragmentation of the management system, and greatly reduce human, financial, Waste in areas such as inability to achieve precise management.

\section{F. Big Data + Artificial Intelligence: The Construction of a New Evaluation and Incentive Mechanism}

Colleges and universities should establish a continuous, pluralistic and comprehensive evaluation system that takes students' ability-oriented as the standard. This is a high-efficiency method for the state, enterprises and all sectors of society to test the achievements of colleges and universities.

"Mirror" is an important tool to promote the connotative and high-quality development of universities. The construction of a new engineering evaluation system under smart education should make full use of the information technology of smart education to establish a "smart" educational evaluation method.

Using big data and artificial intelligence information technology methods to collect data, store analysis, and visualize presentation methods, establish micro-control of students' learning of each knowledge point, focus on the development of students' multiple intelligences, and sense students' psychology, emotions, attitudes, and abilities Changes in various aspects of data encourage students to evaluate independently and provide a better driving force and self-control for learning.

With "speaking by data" as the thinking, process-oriented, and the students' multiple intelligences as the basis for evaluation, the era of wisdom education background, the new 
mechanism of evaluation and motivation of new engineering subjects.

\section{G. Internet of Things + Seamless Interconnection: A Comprehensive Perception of the \\ Government-Industry-University-Research Cooperation System}

The development of new engineering in China's colleges and universities must not be like a "foot-wrapped little woman". At present, if new engineering subjects are to achieve efficient development, they must actively learn from outstanding foreign experience, and at the same time strengthen the combination of "government, industry, research, and research" to build a diversified cooperation and sharing support system. Through the use of information technology such as the Internet of Things and seamless interconnection, build a seamless, stable, secure, and easy-to-use information circulation and data transmission channel [14], which can be a collaborative, adaptive, and friendly online community: Based on customized information push, accessible online communication such as comprehensive network infrastructure, Internet network coverage, etc.

Enable universities to strive to establish joint research institutions with world-class scientific research organizations and universities and multinational companies through the establishment of related project funds, form a flexible and flexible cooperation model, and build a sophisticated and high-level scientific research transformation platform. Second, colleges and universities should increase exchanges and cooperation with industry and engineering guilds and scientific research institutions. Through the establishment of innovative and entrepreneurial laboratories, experimental bases, and the use of the Internet to develop various online school-enterprise cooperation courses, Development trends and market demands of the most cutting-edge industries.. Smart new engineering breaks the "wall" of traditional new engineering and the "fence" of the environmental boundary, eventually turning the university into a smart space where everything is connected. The university and external forces build a green cooperation system that faces the symbiosis and prosperity of reality.

\section{CONCLUSION}

To sum up, in the era of education informatization 2.0, with the promotion of intelligent information technologies such as big data, artificial intelligence, and blockchain, further innovation is taking place in education, which ultimately points to the establishment of a new pattern of intelligent new engineering talent training models, whether it is Educational concepts, environmental platforms, and learning and teaching methods are undergoing irresistible changes, pushing education to become intelligent and digital. The ecological construction of smart new engineering disciplines is conducive to the faster pace of internationalization of higher education in China and to improve China's comprehensive competitiveness. Encourage China's innovation and entrepreneurship education to play a more active role in the construction of the global innovation and entrepreneurship education community and become a mainstay.

\section{CONFLICT OF INTEREST}

The authors declare no conflict of interest.

\section{AUTHOR CONTRIBUTIONS}

Qin Jingyi is responsible for the construction and writing of the entire article idea. Li Hua provides the fine-grained inspection of articles to ensure smooth flow. Chen Xiu is responsible for the detailed analysis of relevant data. Feng Wen collects the related information.

\section{REFERENCES}

[1] X. Zheng, "Smart education 2.0: A new educational ecology from the perspective of educational informatization 2.0-Interpretation of "educational informatization 2.0 action plan"," Journal of Distance Education, vol. 36, no. 4, p. 1119, 2018.

[2] D. Zhong, "Connotation and action of new engineering construction," Research of Higher Engineering Education, vol. 3, pp. 1-6, 2017.

[3] H. Li, N. Hu, and Z. You, "New engineering: Form, connotation and direction," Research of Higher Engineering Education, vol. 6, pp. 16-19, 2017.

[4] Q. Hu, K. Zheng et al., "Research on the system technology deconstruction and integration path of smart education," China Educational Technology, vol. 1, pp. 49-55, 2016

[5] Z. Xu, H. Meng, J. Cheng et al., "IBM's "smart earth" strategy and China's countermeasures," China Science \& Technology Forum, vol. 4, pp. 123-125, 2010.

[6] Z. Zhu and H. Peng, "Smart learning ecology: A systematic methodology for cultivating smart talents," Educational Research on Electronics, vol. 38, no. 4, pp. 5-29, 2017.

[7] H. Ni, Y. Xin, and X. He, "International comparison and enlightenment of innovation capability of research universities," China Higher Education Research, vol. 5, 2017

[8] The ministry of education, "The ministry of education's official website issued a notice: Recommend new engineering research and practice projects, construction of new engineering set sail," Journal of Tianjin University of Applied Sciences, vol. 4, pp. 14-14, 2017.

[9] J. Zhang and D. Ma, "Grounded theory research and management research," Modern Management Science, vol. 2, pp. 115-117, 2009.

[10] W. Chen, Z. Xin, and Z. Shen, "Research on business model based on classical grounded theory," Journal of Beijing University of Posts and Telecommunications (Social Science Edition), vol. 13, no. 3, pp. 81-88, 2011.

[11] L. Chen, Z. Wang et al., ""Internet + Era" Discipline orientation of educational technology and reflections on talent cultivation directions," Research on Electronic Education, vol. 38, no. 10, pp. 5-11, 2017.

[12] Y. Ren, "Smart campus: The turn and challenge of information management in colleges and universities," China Education Letter Informatization, vol. 10, pp. 20-21, 2013.

[13] Stanford president offers predictions on a more digital future for higher education $\quad[\mathrm{EB} / \mathrm{OL}]$ [Online]. Available: https://www.insidehighered.com/news/2015/03/16/stanford-presidentoffers-predictions-more-digitalfuture-higher-education

[14] Z. Ma, The Road to the 2025 Strong Country Made in China and Industry 4.0 Practices, Beijing: People's Posts and Telecommunications Press, 2016.

Copyright (C) 2020 by the authors. This is an open access article distributed under the Creative Commons Attribution License which permits unrestricted use, distribution, and reproduction in any medium, provided the original work is properly cited (CC BY 4.0).

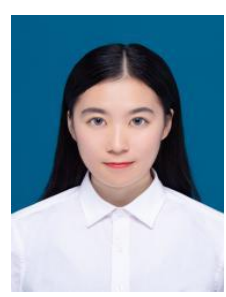

Qin Jingyi was born in Henan Anyang. She is a master student major in higher education in Chongqing University, China. 


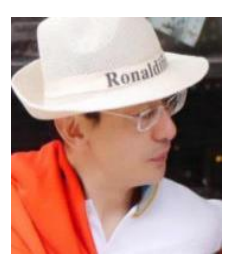

Li Hua was born in Sichuan Province, China, in Nov. 1962. He is the director of the Center for Strategic Research of Engineering Science and Education of Chongqing University and a professor of higher education in Chongqing University. His main research direction is higher education management.

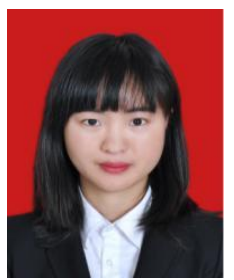

Chen Xiu was born in Sichuan Province, China in Oct. 1994. She is doing her master in Chongqing University majoring in higher educational technology and educational management. She is working as an intern researcher in Chongqing Institute of Educational Sciences.

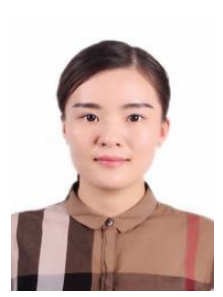

Feng Wen was born in Guizhou Province, China, works in Investment Promotion Bureau of Bishan high tech Industrial Development Zone Management Committee. She has a master's degree in education from School of Public Management, Chongqing University. Her main research direction is higher education management. 